\title{
Intrahepatic Bile Duct Cancer pN1 TNM
} Finding v8

National Cancer Institute

\section{Source}

National Cancer Institute. Intrahepatic Bile Duct Cancer pN1 TNM Finding v8. NCI

Thesaurus. Code C134603.

Intrahepatic bile duct cancer with regional lymph node metastasis. (from AJCC 8th Ed.) 